\title{
Disruption of Bmal1 Impairs Blood-Brain Barrier Integrity via Pericyte Dysfunction
}

\author{
Ryota Nakazato, ${ }^{1}$ Kenji Kawabe, ${ }^{2}$ Daisuke Yamada, ${ }^{2}$ Shinsuke Ikeno, ${ }^{1}$ Michihiro Mieda, ${ }^{3}$ Shigeki Shimba, ${ }^{4}$ \\ Eiichi Hinoi, ${ }^{1}$ Yukio Yoneda, ${ }^{1}$ and Takeshi Takarada ${ }^{1,2}$ \\ ${ }^{1}$ Laboratory of Molecular Pharmacology, Division of Pharmaceutical Sciences, Kanazawa University Graduate School, Kanazawa, Ishikawa 920-1192, Japan, \\ 2Department of Regenerative Science, Okayama University Graduate School of Medicine, Dentistry and Pharmaceutical Sciences, Okayama 700-8558, \\ Japan, ${ }^{3}$ Department of Molecular Neuroscience and Integrative Physiology, Faculty of Medicine, Kanazawa University, Kanazawa, Ishikawa 920-8640, \\ Japan, and ${ }^{4}$ Department of Health Science, College of Pharmacy, Nihon University, Chiba 274-8555, Japan
}

Circadian rhythm disturbances are well established in neurological diseases. However, how these disruptions cause homeostatic imbalances remains poorly understood. Brain and muscle aryl hydrocarbon receptor nuclear translocator-like protein 1 (Bmal1) is a major circadian clock transcriptional activator, and Bmall deficiency in male Bmal1 $1_{\text {nestin }}^{-1-}$ mice induced marked astroglial activation without affecting the number of astrocytes in the brain and spinal cord. Bmall deletion caused blood-brain barrier (BBB) hyperpermeability with an age-dependent loss of pericyte coverage of blood vessels in the brain. Using Nestin-green fluorescent protein (GFP) transgenic mice, we determined that pericytes are Nestin-GFP ${ }^{+}$in the adult brain. Bmall deletion caused Nestin-GFP ${ }^{+}$pericyte dysfunction, including the downregulation of platelet-derived growth factor receptor $\beta$ (PDGFR $\beta$ ), a protein necessary for maintaining BBB integrity. Knockdown of Bmall downregulated PDGFR $\beta$ transcription in the brain pericyte cell line. Thus, the circadian clock component Bmal1 maintains BBB integrity via regulating pericytes.

Key words: blood-brain barrier; Clock gene; pericyte

\section{Significance Statement}

Circadian rhythm disturbances may play a role in neurodegenerative disorders, such as Alzheimer's disease. Our results revealed that one of the circadian clock components maintains the integrity of the blood-brain barrier (BBB) by regulating vascularembedded pericytes. These cells were recently identified as a vital component for the control of BBB permeability and cerebral blood flow. Our present study demonstrates the involvement of circadian clock component Bmall in BBB homeostasis and highlights the role of Bmall dysfunction in multiple neurological diseases.

\section{Introduction}

Circadian rhythms are observed in a variety of physiological processes, including sleep/wake cycles, in organisms ranging from

\footnotetext{
Received Nov. 26, 2016; revised Sept. 4, 2017; accepted Sept. 7, 2017

Author contributions: K.K., D.Y., E.H., Y.Y., and T.T. designed research; R.N., K.K., and S.I. performed research; M.M. and S.S. contributed unpublished reagents/analytic tools; R.N. and S.I. analyzed data; R.N., K.K., D.Y., and T.T. wrote the paper.

This work was supported in part by Grants-in-Aid for Scientific Research on Innovative Areas (26117507 and 16H01332) and for Scientific Research on Innovative Areas (Comprehensive Brain Science Network) to T.T. from the Ministry of Education, Culture, Sports, Science and Technology, Japan; and in part by a research grant to T.T. from the Nakatomi Foundation. We thank Dr. G. Enikolopov (Cold Spring Harbor Laboratory, Cold Spring Harbor, NY), Dr. Jamey D. Marth (University of California, Santa Barbara, Santa Barbara, CA), and Dr. Shigeyoshi Itohara (RIKEN Brain Science Institute, Saitama, Japan) for generously providing the Nestin-GFP, Synapsin I-Cre, and S100 $\beta$-Cre mice, respectively.

The authors declare no competing financial interests.

Correspondence should be addressed to Takeshi Takarada, 2-5-1 Shikata-cho, Kita-ku, Okayama 700-8558, Japan. E-mail: takarada@okayama-u.ac.jp.

DOI:10.1523/JNEUROSCI.3639-16.2017

Copyright $\odot 2017$ the authors $\quad 0270-6474 / 17 / 3710052-11 \$ 15.00 / 0$
}

bacteria to mammals. Circadian rhythmicity is believed to be generated at the cellular level by circadian core oscillators, which not only reside in the suprachiasmatic nucleus (SCN) of the hypothalamus but also in non-SCN brain regions and peripheral tissues (Young et al., 2001; Storch et al., 2002; Mühlbauer et al., 2004; Shimba et al., 2005). Circadian rhythms are generated by circadian locomotor output cycles protein kaput (clock) gene feedback loops. The positive loop is comprised of brain and muscle aryl hydrocarbon receptor nuclear translocator-like protein-1 (Bmal1) and Clock. The Bmal1/Clock complex binds to the E-box motif and regulates the transcription of various genes. The positive loop also promotes the transcription of genes in the negative loop, including period (Per) and cryptochrome (Cry). These proteins negatively regulate gene transcription by inhibiting the transcriptional activity of the Bmall/Clock complex. Once the Per/Cry repressor complex is ubiquitinated and degraded by the proteasome, the Bmal1/Clock complex activates a new transcriptional cycle with oscillatory rhythmicity (Gekakis et 
Table 1. List of primers used for genotyping in this study

\begin{tabular}{|c|c|c|c|}
\hline Mouse & Upstream $\left(5^{\prime}-3^{\prime}\right)$ & Downstream $\left(5^{\prime}-3^{\prime}\right)$ & $\begin{array}{l}\text { Annealing } \\
\text { temperature }\left({ }^{\circ} \mathrm{C}\right)\end{array}$ \\
\hline Bmal $7^{f / / f l}$ mouse (floxed allele) & ACTGGAAGTAACTTTATCAAACTG & CTGACCAACTTGCTAACAATTA & 56 \\
\hline Cre mouse (cre recombinase) & GAACCTGATGGACATGTTCAGG & AGTGCGTTCGAACGCTAGAGCCTGT & 62 \\
\hline Bmal1-deficient mouse (WT allele) & CAAACCTGGTCGTCTGGAAT & GTCCTCCCCAAAAGGTGAAT & 64 \\
\hline Bmal7-deficient mouse (mutant allele) & СTCATCTGCTTATCTGCTCTGGGG & GGGGATTTCCATCTGTGTTTAC & 64 \\
\hline
\end{tabular}

Table 2. List of antibodies used in this study

\begin{tabular}{|c|c|c|c|c|}
\hline Antibody & Origin & Catalog\# & Company & Dilution (TBST) \\
\hline \multicolumn{5}{|l|}{ Primary antibodies } \\
\hline Anti-NeuN & Mouse & MAB377 & Chemicon & $1: 400$ \\
\hline Anti-GFAP & Rabbit & G9269 & Sigma-Aldrich & $1: 200$ \\
\hline Anti-S100 $\beta$ & Mouse & S2532 & Sigma-Aldrich & $1: 200$ \\
\hline Anti-lba1 & Rabbit & 019-19741 & Wako & $1: 200$ \\
\hline Anti-Laminin & Rabbit & L9393 & Sigma-Aldrich & $1: 200$ \\
\hline Anti-Desmin & Rabbit & $a b 8592$ & Abcam & $1: 200$ \\
\hline Anti-CD31 & Rat & 550274 & BD Biosciences & $1: 200$ \\
\hline Anti-CD13 & Goat & AF2335 & R\&D Systems & $1: 200$ \\
\hline Anti-PDGFR $\beta$ & Goat & AF-1042 & R\&D Systems & $1: 100$ \\
\hline Anti-Aqp4 & Rabbit & AB3594 & Millipore & $1: 200$ \\
\hline Anti-CD11b & Rat & MCA711G & AbD Serotec & $1: 200$ \\
\hline Anti- $\alpha S M A$ & Mouse & M0851 & Dako & $1: 200$ \\
\hline Anti-Bmal1 & Rabbit & sc-48790 & Santa Cruz Biotechnology & $1: 200$ \\
\hline \multicolumn{5}{|l|}{ Secondary antibody } \\
\hline Alexa Fluor 488-conjugated goat anti-mouse lgG & & A-11001 & Invitrogen & 1:400 \\
\hline Alexa Fluor 546-conjugated goat anti-mouse lgG & & A-11030 & Invitrogen & $1: 400$ \\
\hline Alexa Fluor 546-conjugated goat anti-rabbit lgG & & A-11035 & Invitrogen & 1:400 \\
\hline Alexa Fluor 633-conjugated goat anti-rabbit lgG & & A-21070 & Invitrogen & $1: 400$ \\
\hline Alexa Fluor 488-conjugated donkey anti-goat IgG & & A-11055 & Invitrogen & 1:400 \\
\hline Alexa Fluor 546-conjugated donkey anti-goat IgG & & A-11056 & Invitrogen & 1:400 \\
\hline Alexa Fluor 488-conjugated goat anti-rat IgG & & A-11006 & Invitrogen & $1: 400$ \\
\hline Alexa Fluor 546-conjugated goat anti-rat lgG & & A-11081 & Invitrogen & $1: 400$ \\
\hline
\end{tabular}

al., 1998; Griffin et al., 1999; Kume et al., 1999; Yamaguchi et al., 2000).

Abnormal sleep behaviors are commonly observed in patients with psychiatric and neurodegenerative diseases. Several studies have suggested that the disruption of circadian rhythm machinery is involved in the pathogenesis of these diseases (Schibler, 2007; Wulff et al., 2010; Kondratova and Kondratov, 2012). Musiek et al. (2013) reported that mice with a targeted deletion of Bmall in the brain showed impaired neuronal connectivity and severe age-dependent astrogliosis, indicating that impaired clock gene function may lead to neurodegeneration. However, how disruption of circadian clock system causes this homeostatic imbalance in the brain remains poorly understood.

Here, we show that gene ablation of Bmal1, a central regulator of the positive feedback loop of the circadian clock system, disrupts blood-brain barrier (BBB) integrity. Bmall deficiency leads to pericyte dysfunction, BBB hyperpermeability, and marked astrogliosis. Thus, our data demonstrate that Bmall function regulates BBB homeostasis in the brain and provide insight into the development of new therapeutic/diagnostic strategies for patients with psychiatric and neurodegenerative diseases.

\section{Materials and Methods}

Animals. Bmal1 ${ }^{-1-}$ mice (Shimba et al., 2011), Bmal1 ${ }^{f l f l}$ mice (stock \#007688, The Jackson Laboratory; Storch et al., 2007), Nestin-Cre mice (stock \#003771, The Jackson Laboratory; Tronche et al., 1999), Synapsin I-Cre (Zhu et al., 2001), S100ß-Cre (Tanaka et al., 2008), and Nestin-GFP mice (Mignone et al., 2004) were backcrossed with C57BL/J mice at least six times. Mice were bred under the following standard animal housing conditions: $23 \pm 1{ }^{\circ} \mathrm{C}, 55 \%$ humidity, $12 \mathrm{~h}$ light/dark cycle, and standard laboratory food and water available ad libitum. RNA was extracted from the calvaria at different diurnal times. Zeitgeber time (ZT) 0 and ZT12 are defined as the time of lights-on and lights-off, respectively. Genotyping was performed by PCR using tail genomic DNA with the primers listed in Table 1 . The study protocol was approved by the Committee for Ethical Use of Experimental Animals at Kanazawa University in Kanazawa, Japan.

Open field test. Adult male mice were tested using a $42.2 \mathrm{~cm}^{2}$ wood board enclosure with $30 \mathrm{~cm}$ walls. Mice were placed at the center of open field, and images were recorded for $10 \mathrm{~min}$. Quantitative analyses were performed using ImageJ software (National Institutes of Health). The $x-y$ coordinates of the mice in each picture were determined using ImageJ to represent the center of mass of the animal. The total distance traveled represents the sum of all displacements of the mouse.

Immunohistochemistry. Adult male mice at age 8-12 weeks were deeply anesthetized with diethyl ether before an intracardial perfusion with saline and $4 \%$ paraformaldehyde. Brains and spinal cords were removed, postfixed overnight, and cryoprotected in 30\% sucrose. For double-immunohistochemical staining, frozen coronal sections were cut at a thickness of $30 \mu \mathrm{m}$ using a cryostat (CM 3050, Leica). Sections were incubated in a blocking solution for $1 \mathrm{~h}$ followed by incubation with the primary antibodies for $24 \mathrm{~h}$ at $4^{\circ} \mathrm{C}$. After washing in PBS, sections were incubated for $2 \mathrm{~h}$ at room temperature with the secondary antibodies. The antibodies used in this study are listed in Table 2. Confocal images were acquired using LSM710 and Zen 2009 software (Carl Zeiss). Quantitative image analyses were performed using ImageJ software. Pericyte coverage (Desmin/CD31 or CD13/CD31) was quantified using ImageJ to measure the percentage area of Desmin ${ }^{+}$or $\mathrm{CD}_{13}{ }^{+}$ pericytes versus $\mathrm{CD} 31^{+}$vessels. The $\mathrm{CD} 31^{+}$area per square millimeter was defined as the vascular density. 
BBB permeability assay. Adult male mice at age 8-12 weeks were intravenously injected with $100 \mathrm{mg} / \mathrm{kg}$ Evans Blue [molecular weight (MW), 961 $\mathrm{Da}$; Tocris Bioscience] or $100 \mathrm{mg} / \mathrm{kg}$ EZ-link sulfo NHS-biotin (MW, 443 Da; Thermo Fisher Scientific). Mice were perfused with saline (Evans Blue) or $4 \%$ paraformaldehyde (EZ-link sulfo NHS-biotin) within $24 \mathrm{~h}$ after the tracer injection. Sections obtained from biotin-injected mice were stained with Alexa Fluor 488-streptavidin (1:400; Invitrogen) and anti-laminin/Alexa Fluor 546-conjugated goat anti-rabbit IgG. Frozen brain coronal sections were viewed with a LSM710 confocal microscope. The leakage of injected biotin into brain parenchyma was quantified using ImageJ software.

Transfection with siRNA. The rodent brain pericyte cell line TR-PCT1 was a gift from Dr. Emi Nakashima (Keio University, Tokyo, Japan; Asashima et al., 2002). TR-PCT1 cells were transfected with $10 \mathrm{~nm} \mathrm{Bmal1}$ siRNA (Sigma Chemical) using Lipofectamine/RNAiMAX (Invitrogen). mRNA expression was determined using quantitative PCR (qPCR) $48 \mathrm{~h}$ after transfection.

Determination of mRNA expression. Cells were washed twice with PBS. The extraction of total RNA using ISOGEN was completed according to the manufacturer instructions. Quantification of PCR products was performed with an iQ SYBR Green Super Mix (BIO-RAD) using real time-based RT-PCR and a Mx3000P qPCR System (Agilent Technologies). The relative amount of each transcript was normalized to glyceraldehyde3-phosphate dehydrogenase (Gapdh) expression from a real time-based RT-PCR(Takarada et al., 2012a). The primer sequences used for qPCR included Pdgfrb: 5'-TATGCTGCAGAACTCGATGG-3', 5'-CCACTT TGAAAGGCAAGGAG-3'; and Gapdh: 5'-CAACTCCCTCAAGATTG TCAGCAA-3' ${ }^{\prime}$ ' '-GGCATGGACTGTGGTCATGA-3' .

Statistical analysis. All data are presented as the mean \pm SEM. Group means were compared using two-way ANOVA with the Bonferroni post hoc test. $p$ values of $<0.05$ were considered to be statistically significant. Each result is representative of three or more independent experiments.

\section{Results}

Bmal1 deletion in Bmal1 $1_{\text {nestin }}^{-1-}$ mice causes astroglial activation in the brain

A previous study by Musiek et al. (2013) demonstrated that brain-specific Bmal1-knock-out mice, generated by crossing Bmalf ${ }^{f l f l}$ mice with Nestin-Cre mice, exhibited marked agedependent cerebral astrogliosis, synaptic degeneration, and behavioral abnormalities, including novelty-induced hyperactivity. We confirmed these phenotypes in Nestin-Cre;Bmalf ${ }^{f / / 1}\left(\right.$ Bmall nestin $\left.^{-1-}\right)$ mice and evaluated whether the astrogliosis observed in $B$ mall $1_{\text {nestin }}^{-1-}$ was due an increase in the total number of astrocytes or an increase in the activation of existing astrocytes. As previously described (Musiek et al., 2013), Bmal1 nestin mice exhibited novelty-induced hyperactivity during open-field testing (Control, $n=9 ;$ Bmall $_{\text {nestin, }}^{-1-}, n=4 ; p=0.0006$; Fig. $1 A$ ). GFAP ${ }^{+}$cells were significantly elevated in the cerebral cortex and hippocampal dentate gyrus of Bmal1 nestin mice $(p=0.002)$; however, the number of $\mathrm{S} 100 \beta^{+}$cells, another astrocyte marker, as well as the number of other neuronal cell markers, including NeuN, CD11b, and Ibal, was comparable in the cerebral cortex between control and Bmal1 ${ }_{\text {nestin }}^{-1}$ mice $(n=3 /$ group; Fig. $1 B-D)$. The percentage of $\mathrm{GFAP}^{+} / \mathrm{S} 100 \beta^{+}$cells was significantly elevated in Bmal1 nestin mice $(p<0.001$; Fig. $1 D)$. Similar results were observed in the spinal cord of Bmal1 nestin $^{-1-}$ mice ( $n=3 /$ group; number of cells, $p=$ 0.003; percentage of $\mathrm{GFAP}^{+} / \mathrm{S} 100 \beta^{+}$cells, $p=0.008$; Fig. $1 E$ ). These data suggest that the deletion of Bmall does not increase the number of astrocytes but rather increases the activation of pre-existing astrocytes.

\section{Bmal1 deletion in Bmal1 nestin $^{-1-}$ mice causes BBB hyperpermeability via pericyte loss}

Astrocytes contribute to the regulation of neural transmission and progression of neurodegeneration and, along with endothe- lial cells and pericytes in the CNS, are a key component of $\mathrm{BBB}$ (Zloković, 2008; Segura et al., 2009). A decline in BBB integrity induces the leakage of blood-derived factors and subsequent astroglial activation (Adornato and Lampert, 1971; Brett et al., 1995; Schachtrup et al., 2010). To determine the cause of astrocyte activation in Bmal1 $1_{\text {nestin }}^{-1-}$ mice, we assessed BBB integrity in these mice at age $8-10$ weeks. We evaluated the water content of Bmall $_{\text {nestin }}^{-1-}$ brains by measuring the ratio of wet weight to dry weight. The water content of the brain was significantly higher in $B m a l 1_{\text {nestin }}^{-1-}$ mice when compared with control mice (control, $n=$ 6; Bmal1 1estin, $n=5 ; p=0.027$; Fig. $2 A)$. Bmal1 $1_{\text {nestin }}^{-1-}$ mice showed an increased vascular permeability to Evans Blue dye $(100 \mathrm{mg} / \mathrm{kg}$; Fig. $2 B)$ and biotin $(100 \mathrm{mg} / \mathrm{kg} ; n=3 /$ group; percentage of control leakage area, $p=0.014$; Fig. $2 C$ ) throughout the CNS parenchyma, suggesting that Bmall deletion leads to BBB hyperpermeability.

Next, we assessed endothelial cells and pericytes, which are essential for the maintenance of BBB integrity. Pericytes are embedded in the basement membrane of blood vessels, and the pericyte coverage of blood vessels in the CNS inversely correlates with BBB permeability in embryos and adult brains (Bell et al., 2010; Daneman et al., 2010). Double-immunohistochemical analysis for CD31 (marker for endothelial cells) and pericyte markers, including Desmin and CD13, clearly showed the progressive loss of pericyte coverage in the cerebral cortex of 10-week-old $B$ Bmal $1_{\text {nestin }}^{-1-}$ mice compared with littermate controls ( $n=3 /$ group; Desmin, $p=0.044$; CD13, $p=0.001$; Fig. $2 D$ ). Platelet-derived growth factor receptor $\beta$ (PDGFR $\beta$ ) is another pericyte marker. Bmal1 nestin mice showed a drastic decrease in the number of PDGFR $\beta^{+}$cells in the cerebral cortex $(n=3$ /group; $p=0.004$; Fig. 2D). Aquaporin 4 (Aqp4) is a water channel protein that is expressed in astrocyte end-feet nearest the neurovascular unit, and it is involved in brain volume homeostasis and in the pathogenesis of brain edema (Nielsen et al., 1997). In control mice, Aqp4 expression was observed in the $\mathrm{CD} 31^{+}$endothelial lining of the vasculature, namely in perivascular glial processes, as reported previously (Nielsen et al., 1997). However, Bmal1 nestin mice exhibited a drastic decrease in the Aqp $4^{+}$area in the cerebral cortex $(n=3 /$ group; $p=0.021$; Fig. $2 E)$.

Moreover, astroglial activation and the loss of pericyte marker expression were age dependent. These parameters were not observed in Bmal1 $1_{\text {nestin }}^{-1-}$ mice at age 1 and 2 weeks, but they were detected at age 4 weeks ( $n=3$ /group; number of GFAP ${ }^{+}$cells, $p=0.019$; percentage of Desmin ${ }^{+}$cells, $p=0.045$; percentage of $\mathrm{CD} 3^{+}$cells, $p=0.034$; number of PDGFR $\beta^{+}$cells, $p=0.048$; Fig. $3 A, B)$. Thus, our results indicate that Bmall deletion causes pericyte dysfunction and BBB hyperpermeability.

\section{Bmal1 deletion causes dysfunction of Nestin-GFP ${ }^{+}$pericytes in the brain}

The loss of pericytes and BBB hyperpermeability occurs in Nestin-Cre-targeted and/or lineage cells that are Bmall deficient. Although the typical lineage cells of Nestin-Cre-targeted cells are neurons and astrocytes, neuron-specific (Bmal1 synapsinI $)$ and astrocyte-specific $\left(\right.$ Bmal1 $\left._{\text {sloo }}^{-1-}\right)$ Bmall knock-out mice did not exhibit any abnormal phenotypes, including hyperactivity in open-field testing (Fig. 4A), astroglial activation (Fig. 4B), and decreased pericyte coverage and PDGFR $\beta$ expression (Fig. $4 C$ ) in the brain. The intermediate filament protein Nestin, which was first reported as a marker of neuroectoderm progenitors (Lendahl et al., 1990), is expressed in pericytes (Alliot et al., 1999; DoreDuffy et al., 2006). In transgenic mice expressing GFP under control of the $5.8 \mathrm{~kb}$ promoter and $1.8 \mathrm{~kb}$ second intron of the Nestin gene (Nestin-GFP ${ }^{+}$; Mignone et al., 2004; Ono et al., 
A
Control

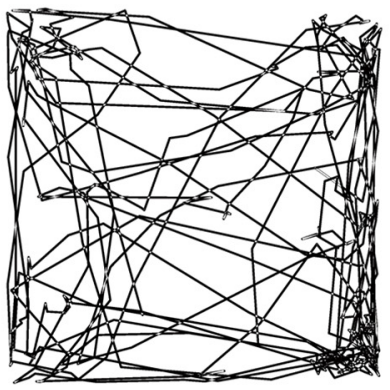

B

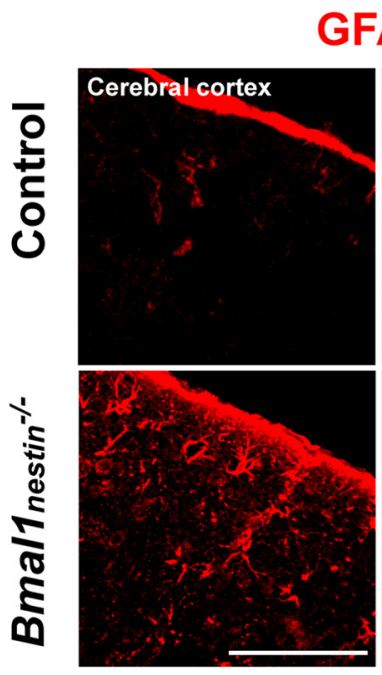

D

GFAP

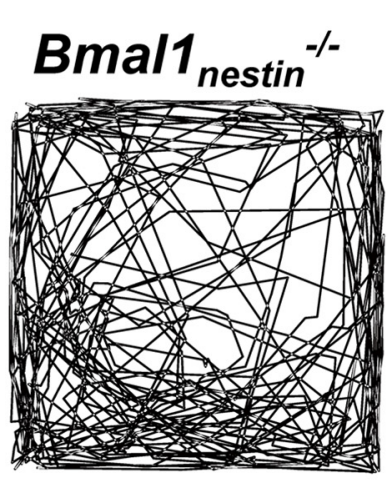

C
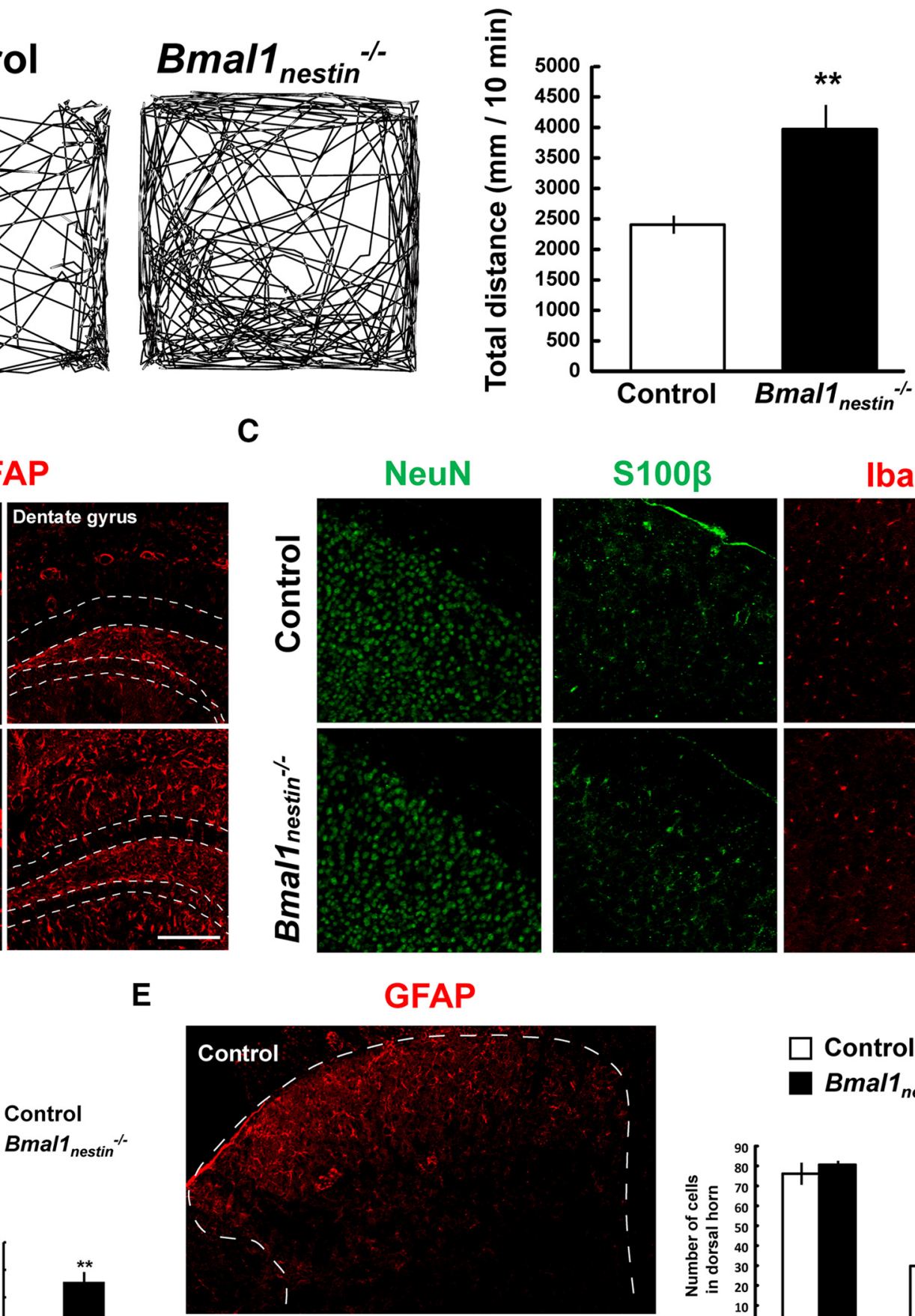

E

Control

Bmal1 $_{\text {nestin }}{ }^{-/-}$
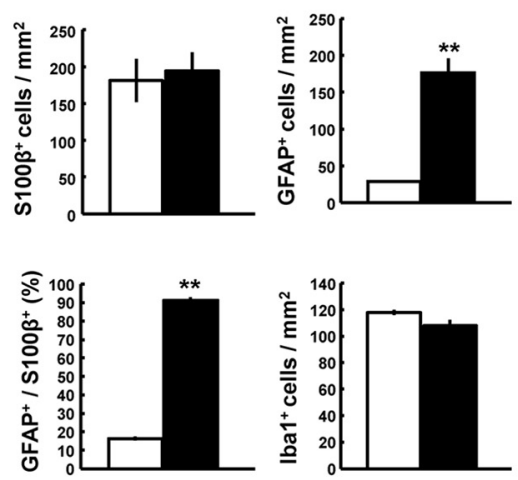

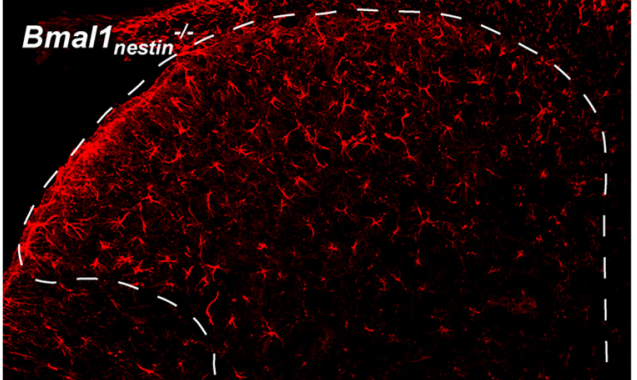

Control

Bmal1 nestin $^{-/-}$

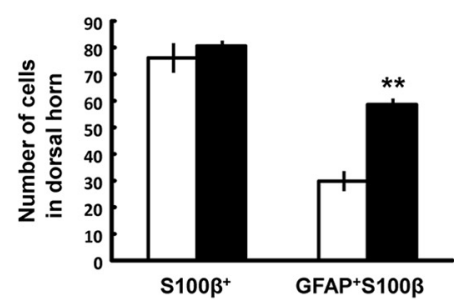

Iba1
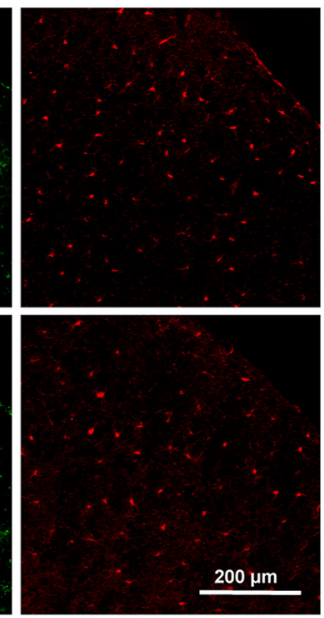

$S 100 \beta^{+}$

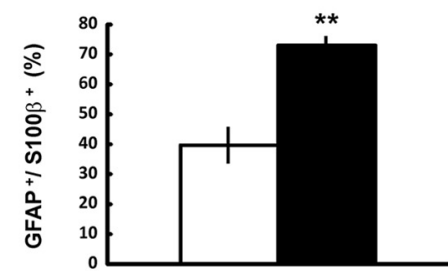

Figure 1. Astroglial activation in Bmal1 $n_{\text {nestin }}^{-1-}$ mice. $A$, open field test to measure novelty-induced locomotor activity of $B m a l 1_{\text {nestin }}^{-1-}$ mice at age $8-12$ weeks $\left(\right.$ control, $\left.n=9 ; B m a l 1_{\text {nestin }}^{-1-}, n=4\right)$. $B$, Immunohistochemical analysis of GFAP in the cerebral cortex and hippocampal dentate gyrus of $B$ mal 1 nestin mice at age $8-12$ weeks. The area surrounded by a white dashed line denotes the granule cell layer of dentate gyrus. C, Immunohistochemical analysis of NeuN, S100 $\beta$, and lba1 in the cerebral cortex of Bmal1 $1_{\text {nestin }}^{-1-}$ mice at age $8-12$ weeks. D, Quantification of NeuN ${ }^{+}, G F A P^{+}$, $\mathrm{S} 100 \beta^{+}$, and Iba ${ }^{+}$cells in the cerebral cortex of control and Bmal1 $1_{\text {nestin }}^{-1-}$ mice at age $8-12$ weeks (control, $n=3 ; B$ mal $1_{\text {nestin }}^{-1-} n=3$ ). E, Immunohistochemical analysis of GFAP (red) and S100 $\beta$ (green) in the spinal cord of Bmal1 $1_{\text {nestin }}^{-1-}$ mice (control, $n=3 ; B$ mall $1_{\text {nestin }}^{-I-}, n=3$ ). The area surrounded by a white dashed line denotes the dorsal horn of the spinal cord. The number of positive cells per square millimeter was calculated. ${ }^{* *} p<0.01$ when compared with littermate controls. 
A

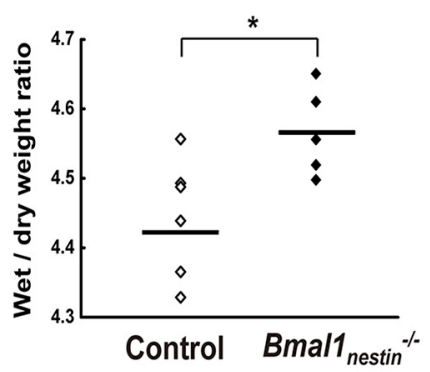

D
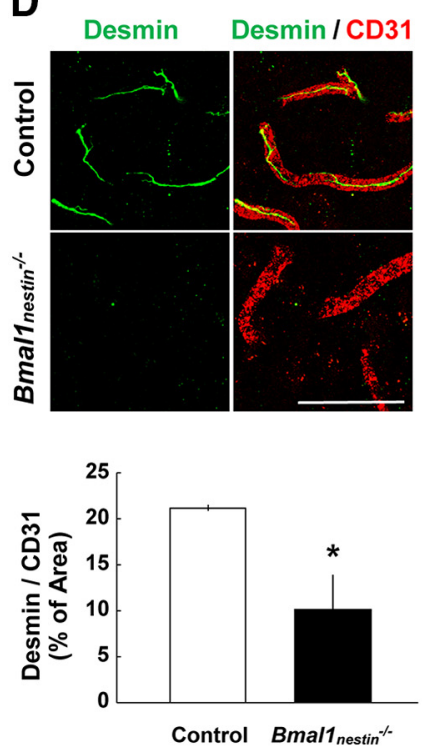
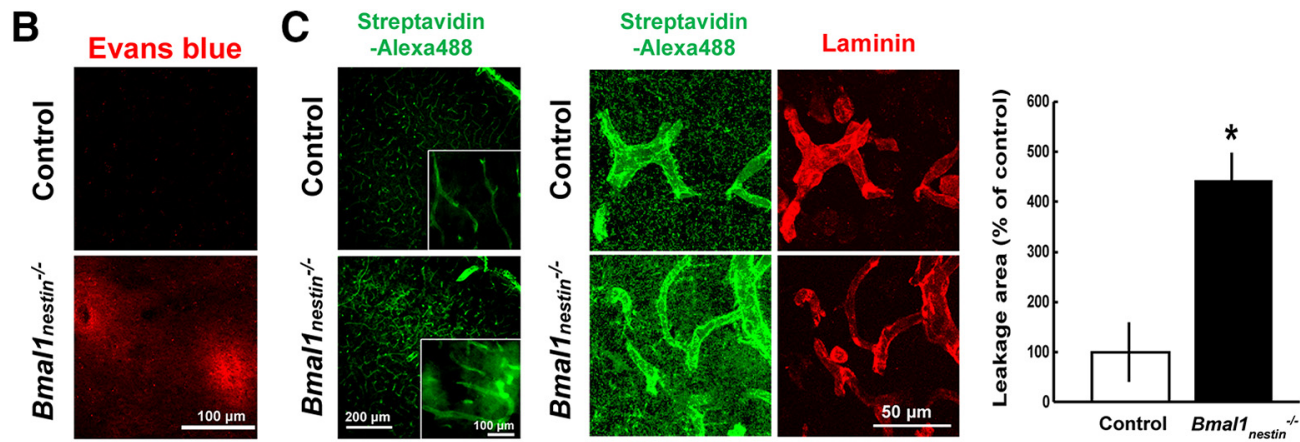

E
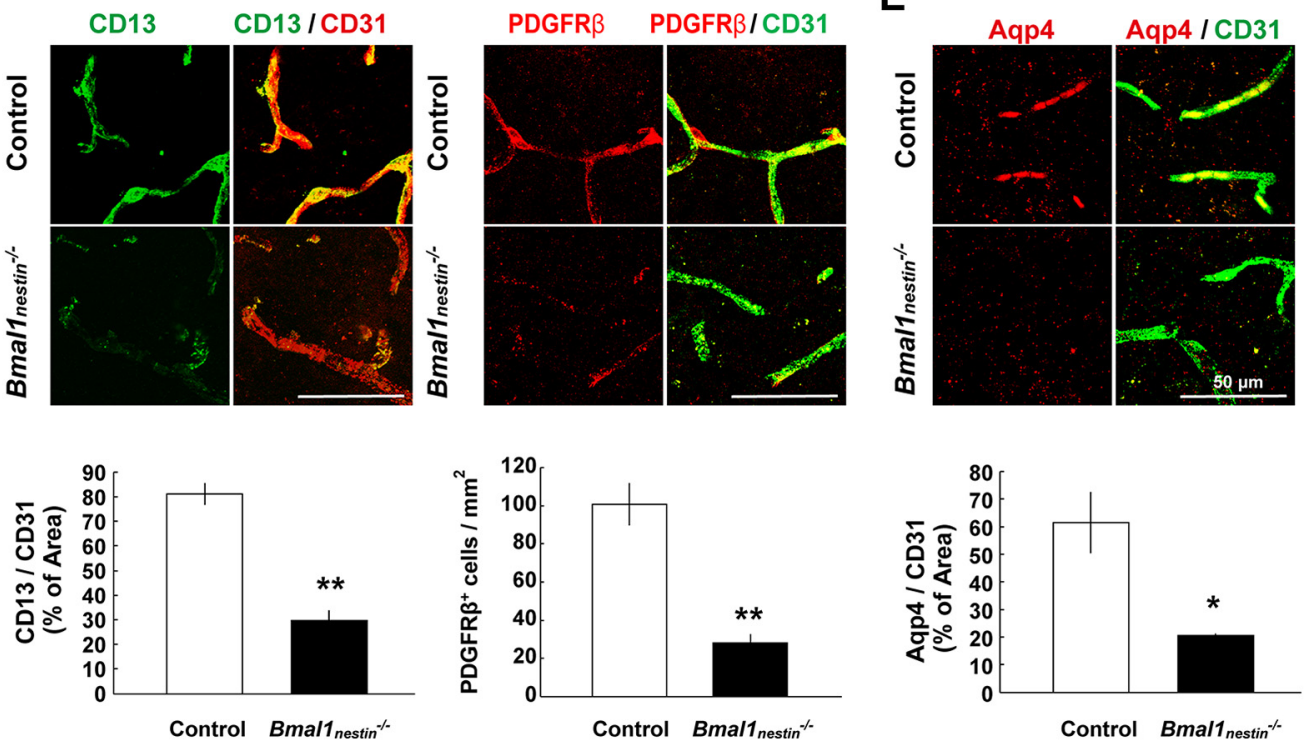

Figure 2. BBB hyperpermeability in Bmal1 1 nestin mice. $A$, Wet/dry weight ratios of control and $B$ mal1 $1_{\text {nestin }}^{-1-}$ mice (control, $n=6 ; B$ mal1 $1_{\text {nestin }}^{-1-}, n=5$ ). $B$, Confocal images of the cerebral cortex of mice injected with Evans Blue after $24 \mathrm{~h}$ of circulation. C, Confocal images of the cerebral cortex in mice injected with biotin after $24 \mathrm{~h}$ of circulation. Sections were stained with Alexa Fluor 488-streptavidin (1:400; Invitrogen) and anti-laminin/Alexa Fluor 546-conjugated goat anti-rabbit lgG. The leakage area of biotin was quantified (control, $n=3 ; B m a l 1_{\text {nestin }}^{-1-}, n=3$ ). $D$, Three-dimensional reconstruction of confocal image $z$-stacks of cerebral cortex vasculatures depicted by CD31 (endothelial cells), Desmin (pericytes), CD13 (pericytes), and PDGFR $\beta$ (pericytes) in Bmal1 $1_{\text {nestin }}^{-1-}$ mice at age 8-12 weeks. Vascular density, pericyte coverage, and the number of PDGFR $\beta^{+}$cells were calculated (control, $n=3 ; B m a l 1_{\text {nestin }}^{-1-} n=3$ ). $\boldsymbol{E}$, Confocal images of Aqp4 (astrocyteend-feet) and $\mathrm{CD} 31$ in the cerebral cortex of $\mathrm{Bmal1}_{\text {nestin }}^{-1-}$ mice. The Aqp4 ${ }^{+}$area was calculated (control, $n=3 ; B$ mall $1_{\text {nestin }}^{-1-}, n=3$ ). ${ }^{*} p<0.05 ;{ }^{* *} p<0.01$ when compared with littermate controls.

2014), Nestin-GFP ${ }^{+}$cells were observed throughout the cerebral cortex (Fig. 5A), hippocampus (Fig. 5-1 $A$ available at 10.1523/ JNEUROSCI.3639-16.2017.f5-1), and the spinal cord (Fig. 5B). Immunohistochemical analysis clearly revealed that Nestin$\mathrm{GFP}^{+}$cells were positive for Bmall in the cerebral cortex (Fig. $5 C)$. Next, we assessed the cell types of Nestin-GFP ${ }^{+}$cells via immunohistochemical analysis. Nestin-GFP ${ }^{+}$cells in the cerebral cortex were negative for NeuN, GFAP, and CD11b and were positive for Desmin, CD13, and PDGFR $\beta$ (Fig. $5 D, E$, and Fig. 5-1 B, $C$ available at 10.1523/JNEUROSCI.3639-16.2017.f5-1). In addition, these cells were present near $\mathrm{CD} 31^{+}$endothelial cells and $\alpha$-smooth muscle actin $(\alpha \mathrm{SMA})^{+}$vascular smooth muscle cells, indicating that brain pericytes are Nestin-GFP ${ }^{+}$cells.

To determine whether the Bmall deletion changes the properties of Nestin-GFP ${ }^{+}$pericytes, we generated the global Bmall-knock-out $\left(\right.$ Bmal1 $\left.^{-l^{-}}\right)$mice expressing the GFP under the Nestin promoter (Nestin-GFP $\mathrm{Bmal1}^{-1-}$ ) by crossing Bmal1 ${ }^{-1-}$ mice with NestinGFP mice $\left(n=4\right.$ /group). In 8-week-old Nestin-GFP ${ }^{+}$Bmal1 ${ }^{-1-}$ mice, $\mathrm{GFAP}^{+}$-activated astrocytes were markedly increased surrounding the Nestin-GFP ${ }^{+}$cells in the cerebral cortex (Fig. 6A). On the other hand, the number of Nestin-GFP ${ }^{+}$cells were comparable between Nestin-GFP ${ }^{+}$Bmal1 $^{+/+}$and Nestin-GFP ${ }^{+}$Bmal1 $^{-1-}$ mice (Fig. $6 A, G$ ). In addition, the areas of $\mathrm{CD} 31^{+}$endothelial cells (vascular density; Fig. $6 B, G$ ) and $\alpha \mathrm{SMA}^{+}$smooth muscle cells (Fig. 6C,G) were comparable between Nestin-GFP $\mathrm{Bmal1}^{+/+}$and Nestin-GFP ${ }^{+}$Bmal1 $^{-1-}$ mice. However, the significant decreases were seen in the percentages of Desmin ${ }^{+}(p=0.008$; Fig. $6 D, G)$, $\mathrm{CD}^{+} 3^{+}(p=0.002$; Fig. $6 E, G)$, and PDGFR $\beta^{+}$cells $(p<0.001$; Fig. $6 F, G)$ among Nestin-GFP ${ }^{+}$cells. These results suggesting that Bmall deletion should not cause the "loss" of pericyte, but the "dysfunction" of Nestin-GFP ${ }^{+}$pericytes in CNS.

PDGFR $\beta$ is a receptor for PDGF-BB secreted from endothelial cells. Precise PDGF-BB/PDGFR $\beta$ signaling is essential for maintaining BBB integrity in the CNS (Winkler et al., 2011). Mice with partially disrupted PDGF-BB/PDGFR $\beta$ signaling exhibited agedependent BBB breakdown (Armulik et al., 2010; Daneman et al., 2010). Therefore, we assessed whether circadian clock proteins regulate PDGFR $\beta$ expression in pericytes. $P d g f r b$ expression was evaluated in the TR-PCT1 brain pericyte cell line. Bmall knockdown by siRNA decreased the expression of $P d g f r b$ in the TRPCT1 cells (siControl, $n=5$; siBmal1, $n=3 ; p<0.001$; Fig. $6 H$ ). These experiments revealed that PDGFR $\beta$ transcription is positively controlled by Bmal1, suggesting that the decreased Bmal1 expression in Nestin-GFP ${ }^{+}$pericytes is responsible for downregulating PDGFR $\beta$ expression in Bmal1 $1_{\text {nestin }}^{-/-}$mice. 
A
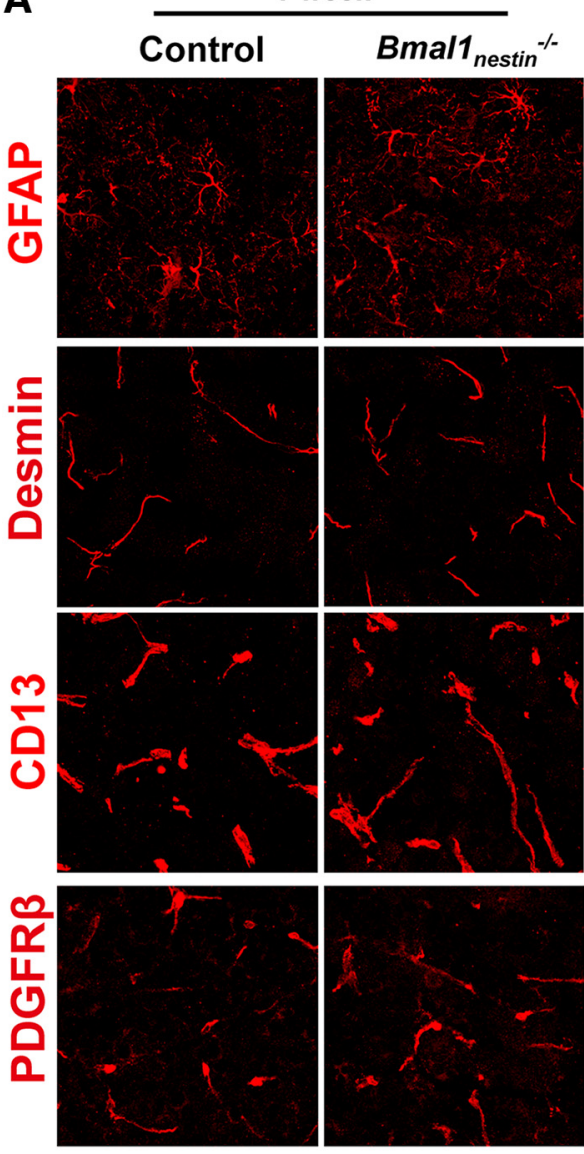

B
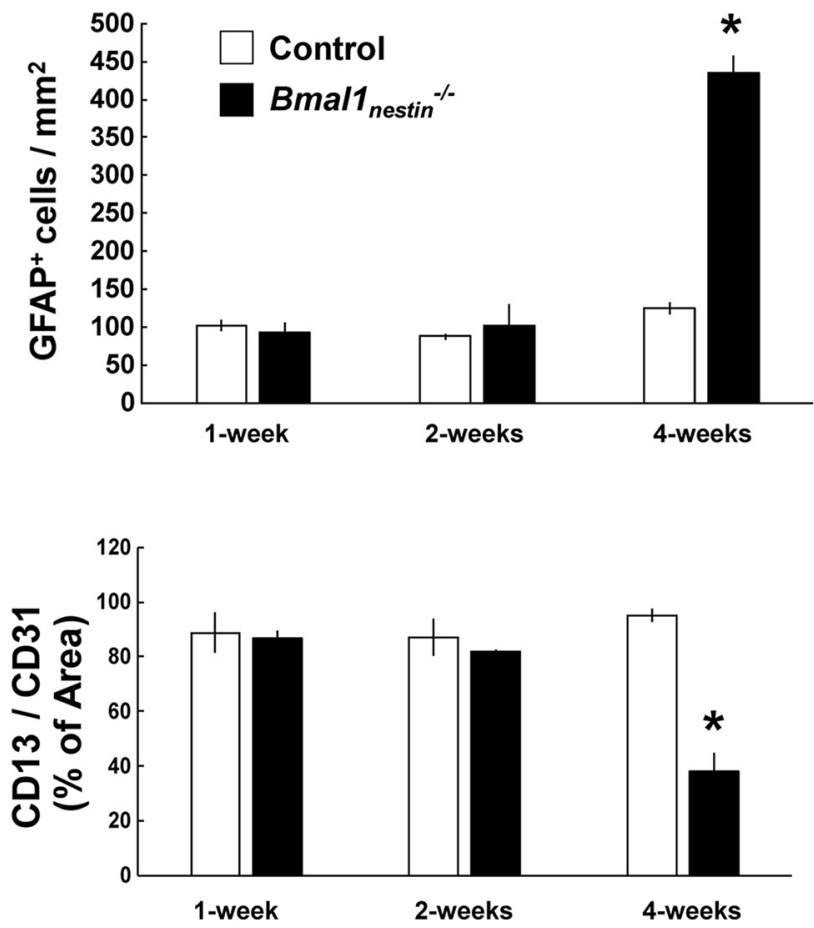

2-weeks
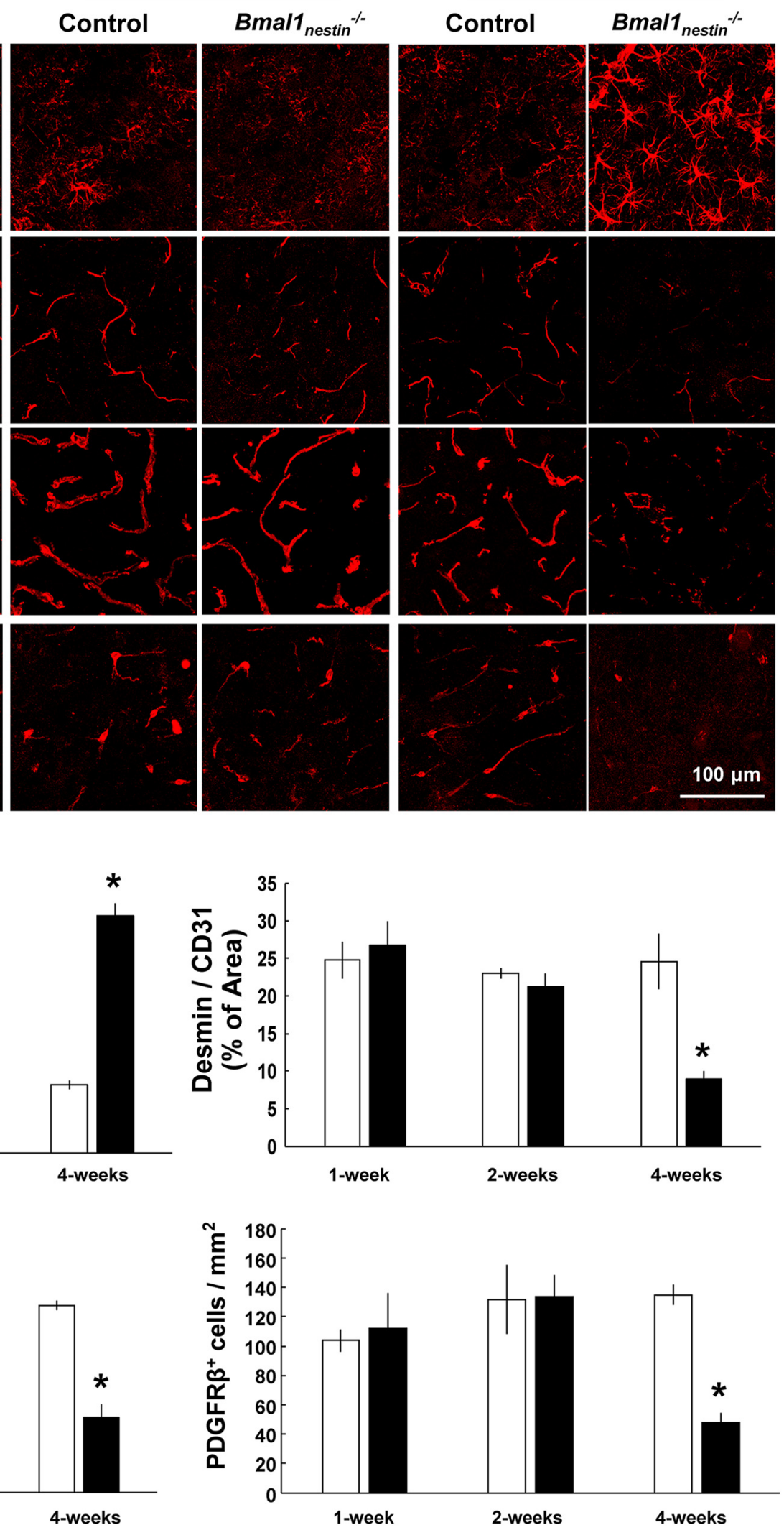

Figure 3. Cerebral astroglial activation and the loss of pericyte marker expression in Bmal1 $1_{\text {nestin }}^{-1-}$ mice are age dependent. $A$, Confocal images of GFAP, Desmin, CD13, and PDGFR $\beta$ in the cerebral cortex of $B$ mal $1_{\text {nestin }}^{-1-}$ mice at 1,2, and 4 weeks of age. $\boldsymbol{B}$, Quantification of GFAP ${ }^{+}$and PDGFR $\beta^{+}$cells in the cerebral cortex of control and $B$ mal $1_{\text {nestin }}^{-1-}$ mice at various time points. The percentage areas of Desmin ${ }^{+}$or $\mathrm{CD} 13^{+}$pericytes vs $\mathrm{CD} 31^{+}$vessels were calculated (control, $n=3 ; B$ mal1 $1_{\text {nestin }}^{-1-} n=3$ ). ${ }^{*} p<0.05$ compared with littermate controls. 
A

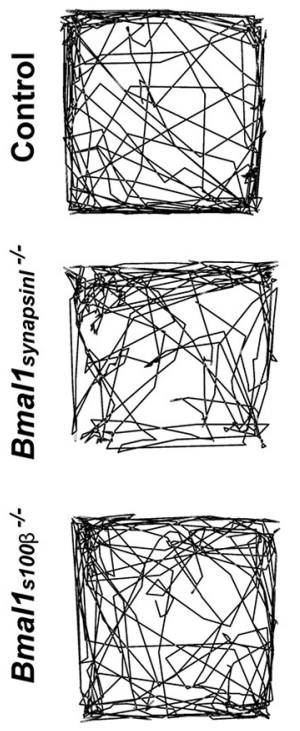

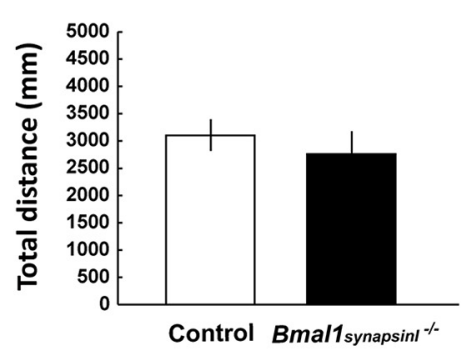

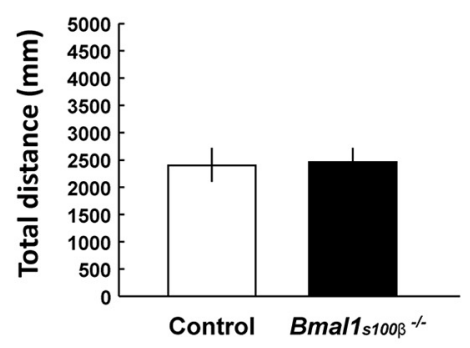

B
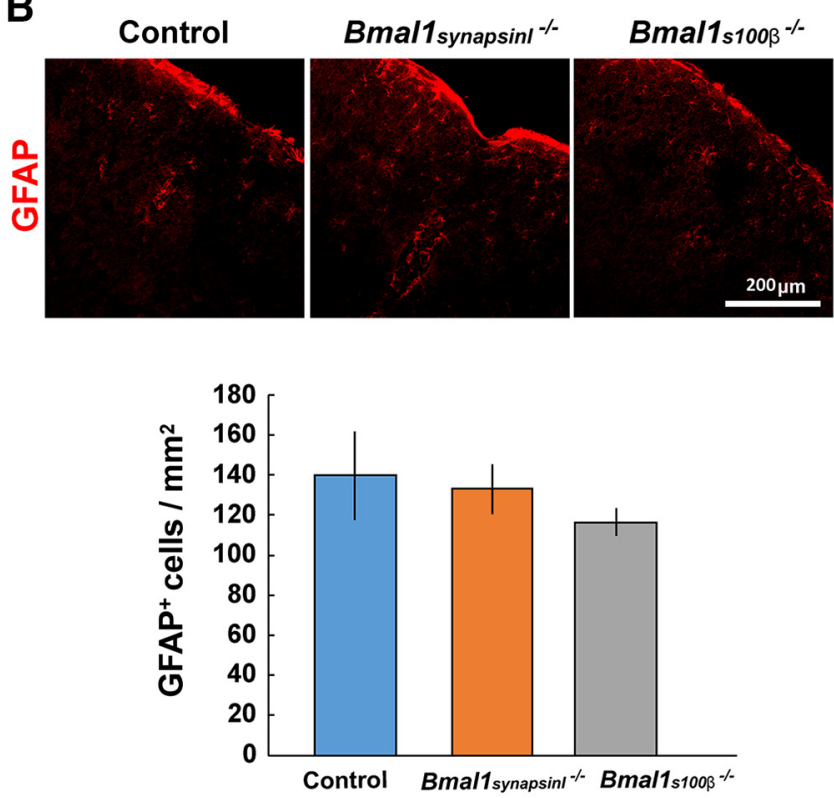

C
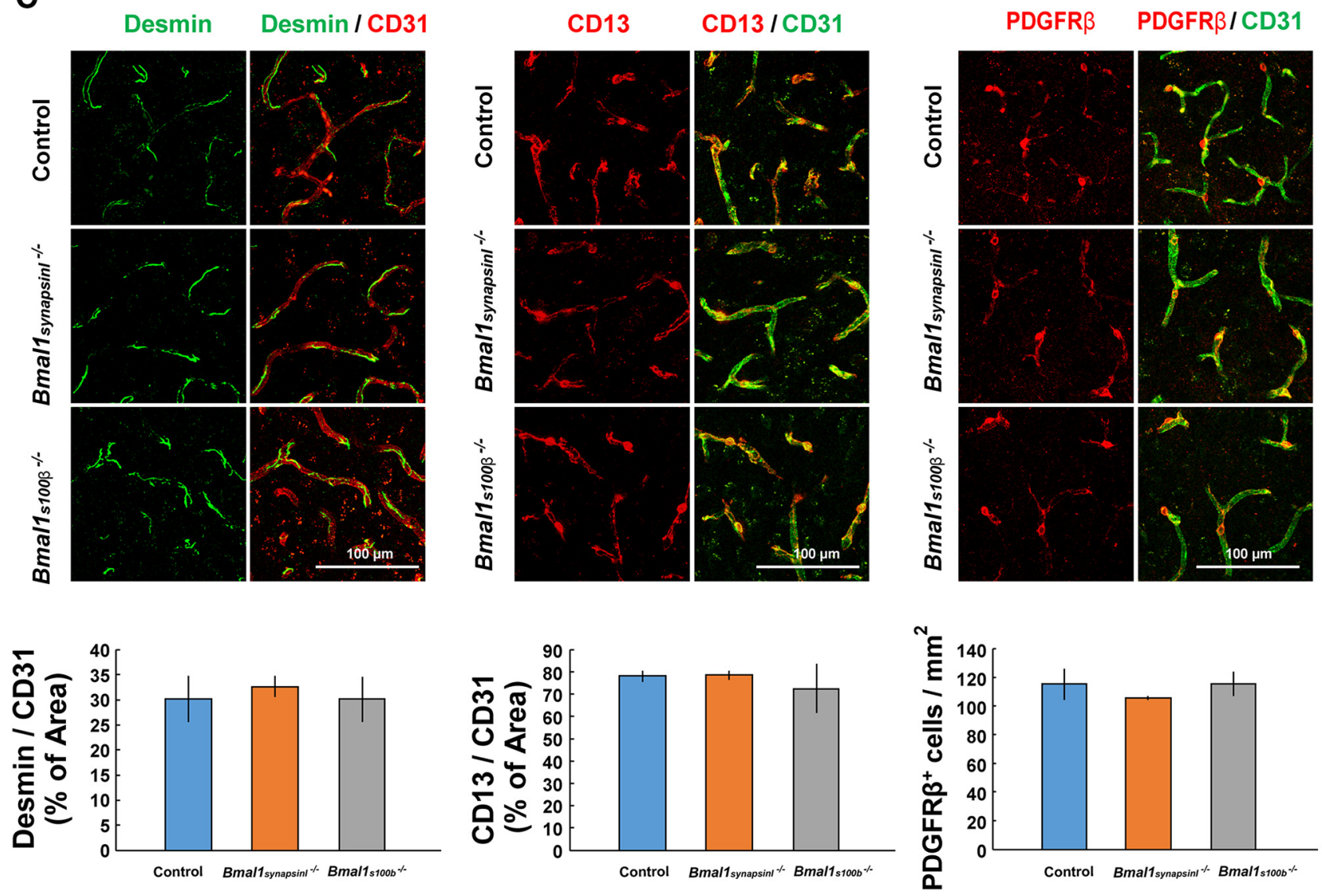

Figure 4. Neuron-specific (Bmal1

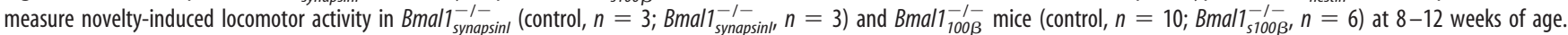
$B$, Immunohistochemical analysis of GFAP in the cerebral cortex of Bmal1 $1_{\text {synapsinl }}^{-1-}$ and $B m a l 1_{s 100 \beta}^{-1-}$ mice at age $8-12$ weeks. The number of positive cells per square millimeter was calculated. C, Confocal image of cerebral cortex vasculatures depicted by CD31, Desmin, CD13, and PDGFR $\beta$ staining in Bmal1 synapsinl $^{-1-}$ and $B m a l 1_{\text {s10o } \beta}^{-1-}$ mice at age $8-12$ weeks. The percentage area of Desmin ${ }^{+}$ or $\mathrm{CD} 13^{+}$pericytes vs $\mathrm{CD} 31^{+}$vessels and the number of PDGFR $\beta^{+}$cells were calculated.

\section{Discussion}

The essential finding of this study is that the disruption of Bmal1, which is part of the positive feedback loop of the circadian clock system, induces pericyte dysfunction and BBB hyperpermeabil- ity. In contrast to the vessels in peripheral organs, $\mathrm{BBB}$ restricts the entry of polar molecules into the brain (Mann et al., 1985; Zloković et al., 1985a,b; Zlokovic and Apuzzo, 1997). However, some molecules can be transported into the brain via specific 
A
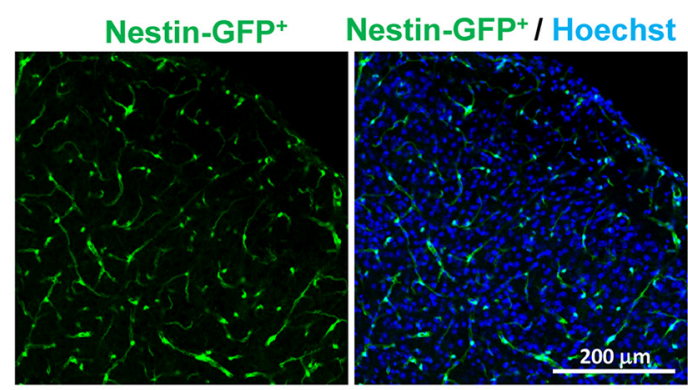

B

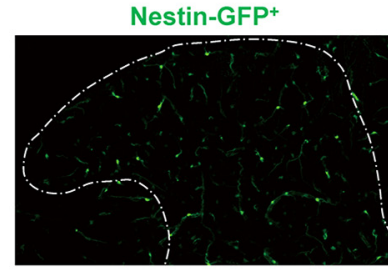

Nestin-GFP ${ }^{+}$I Hoechst

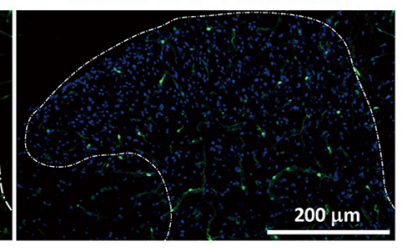

D

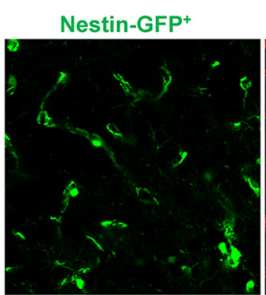

NeuN

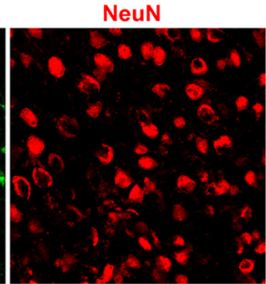

Nestin-GFP + NeuN

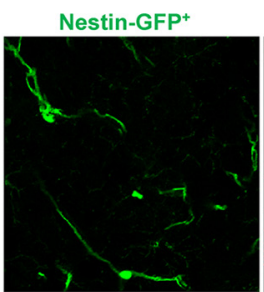

GFAP

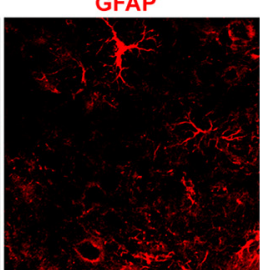

Nestin-GFP+

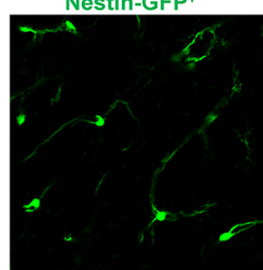

Nestin-GFP+

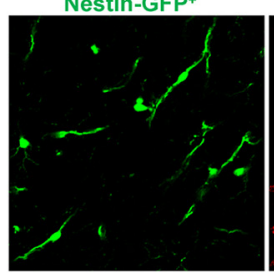

Nestin-GFP+

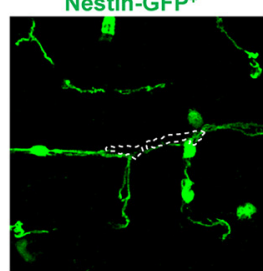

CD11b

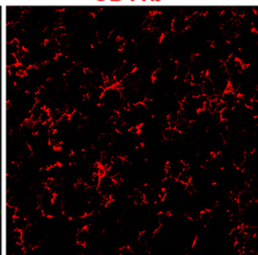

CD31

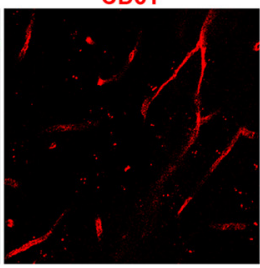

aSMA

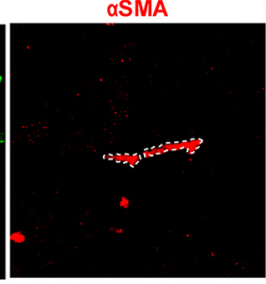

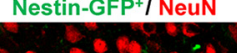

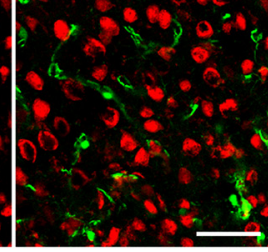

Nestin-GFP ${ }^{+} /$GFAP

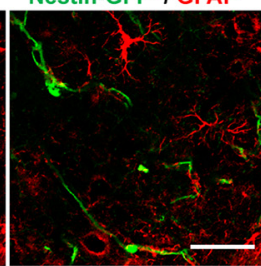

Nestin-GFP + / CD11b

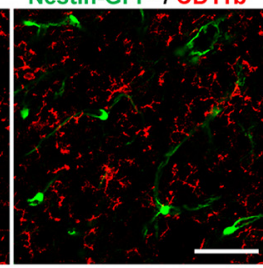

Nestin-GFP+ / CD31

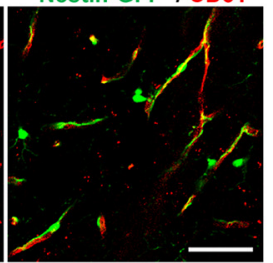

Nestin-GFP + / aSMA / CD31

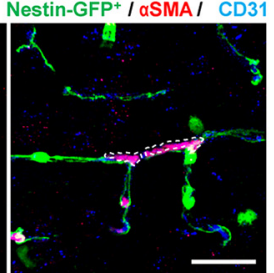

C

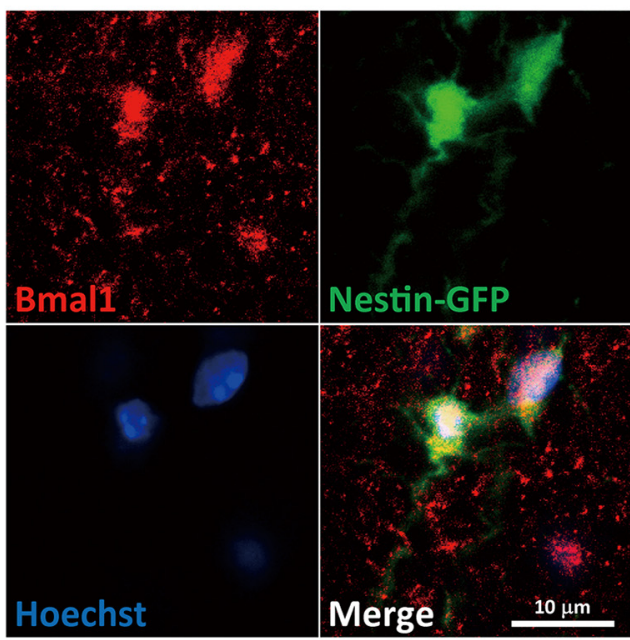

Nestin-GFP+

Desmin

Nestin-GFP ${ }^{+} /$Desmin
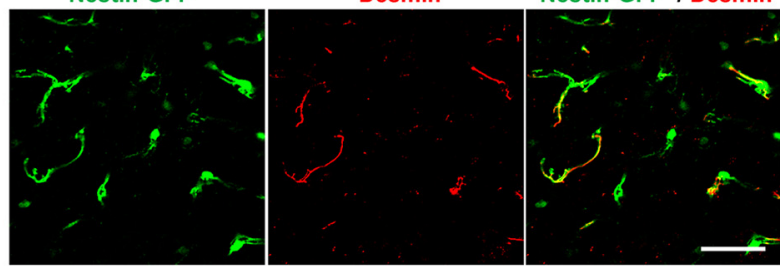

Nestin-GFP

CD13

Nestin-GFP ${ }^{+} /$CD13
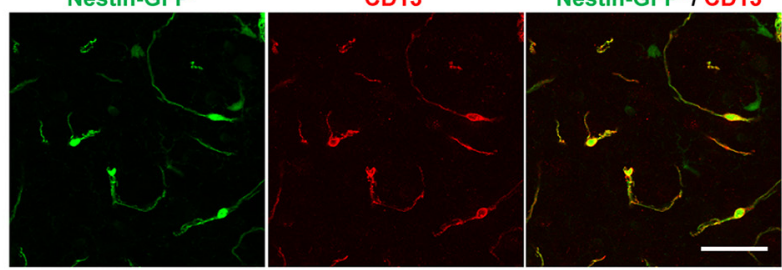

Nestin-GFP*

PDGFR $\beta$

Nestin-GFP ${ }^{+} /$PDGFR $\beta$

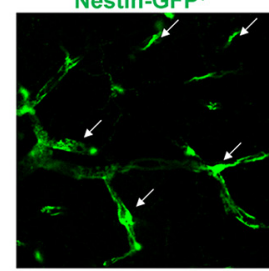

E

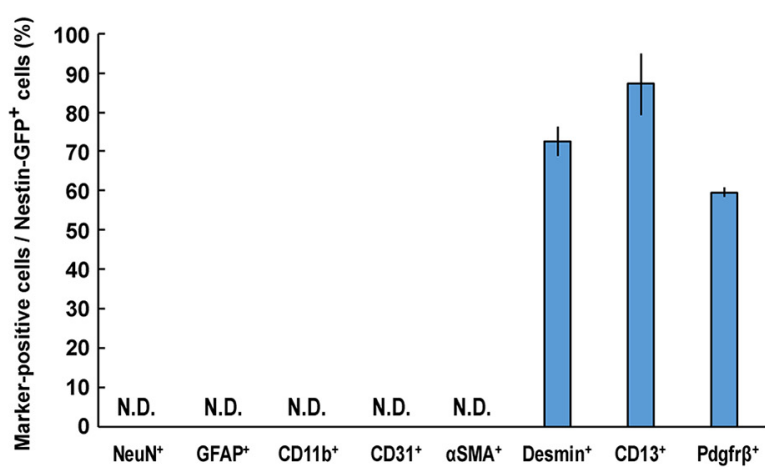

Figure 5. Pericytes in the brain are Nestin-GFP ${ }^{+} . \boldsymbol{A}, \boldsymbol{B}$, Confocal image of GFP (green) and Hoechst 33342 DNA staining (blue) in the cerebral cortex ( $\boldsymbol{A}$ ) or spinal cord ( $\boldsymbol{B}$ ) of Nestin-GFP transgenic mice at age $8-12$ weeks. The area surrounded by a white dashed line denotes the dorsal horn of the spinal cord. $C$, Immunohistochemical analysis of Bmal 1 in the cerebral cortex of Nestin-GFP+ mice at 8-12 weeks of age. D, Immunohistochemical analysis of NeuN, GFAP, CD11b, CD31, $\alpha$ SMA, Desmin, CD13, and PDGFR $\beta$ in the cerebral cortex of Nestin-GFP ${ }^{+}$mice at age $8-12$ weeks. The area surrounded by a white dashed line denotes the $\alpha \mathrm{SMA}{ }^{+}$area. Arrows indicate the PDGFR ${ }^{+}$cells. $\boldsymbol{E}$, The percentage of each marker-positive cell type among (Figure legend continues.) 
A

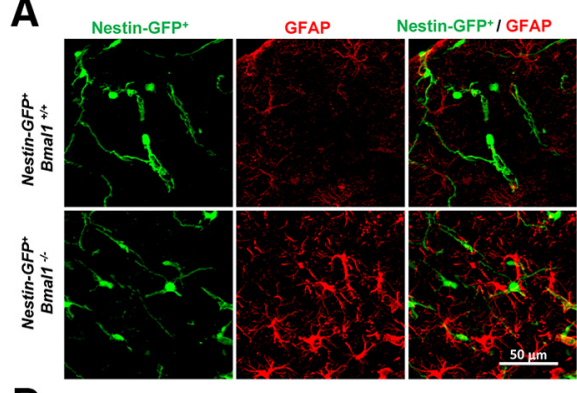

D

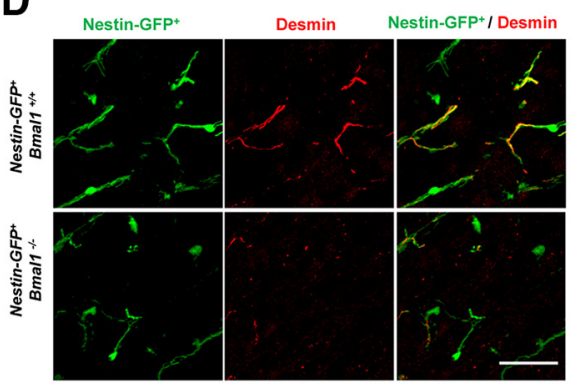

G
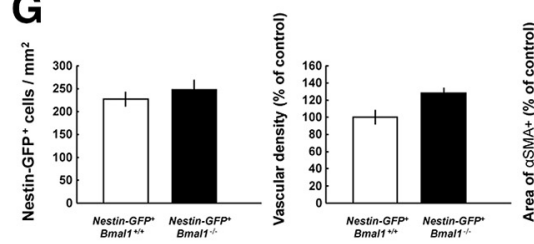

B

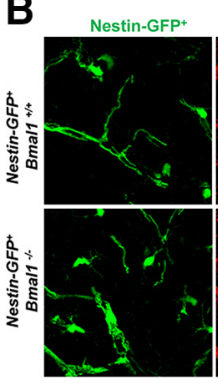

E
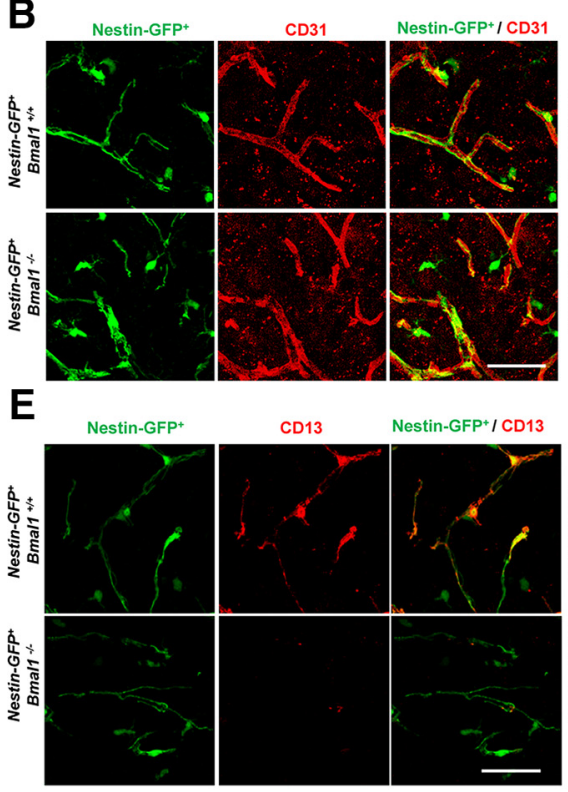

C

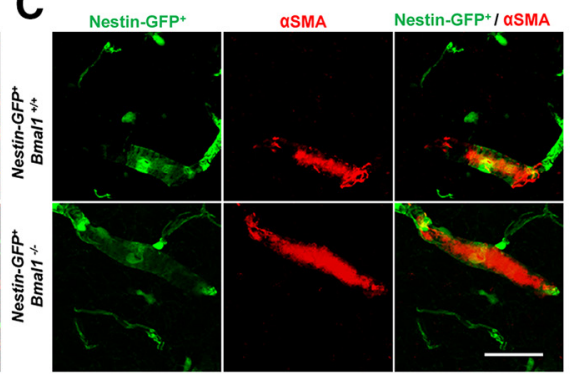

$F$
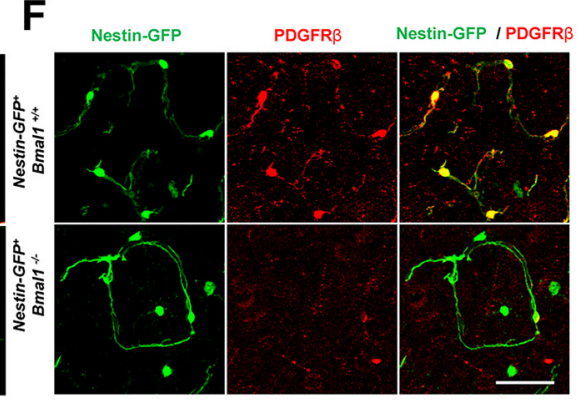

H
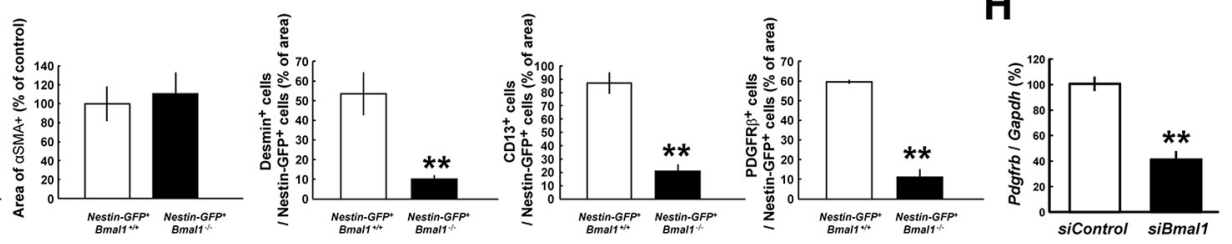

Figure 6. Deficiency of Bmal1 downregulates PDGFR $\beta$ expression in Nestin-GFP ${ }^{+}$pericytes. $A-F$, Immunohistochemical analysis of GFAP (A), CD31 (B), $\alpha$ SMA (C), Desmin (D), CD13 (E), and PDGFR $\beta(\boldsymbol{F})$ in the cerebral cortex of Nestin-GFP ${ }^{+}$Bmal $1^{-1-}$ and Nestin-GFP ${ }^{+} B m a l 1^{+/+}$mice. The presented images are three-dimensional reconstructions of $z$-stacks. $G$, The number of positive cells among Nestin-GFP ${ }^{+}$cells per square millimeter, vascular density, and the $\alpha \mathrm{SMA}^{+}$area were calculated (Nestin-GFP ${ }^{+}$Bmal1 $^{+/+}, n=4 ;$ Nestin-GFP $^{+}$Bmal1 $\left.{ }^{-\prime-}, n=4\right) .{ }^{* *} p<0.01$ compared with littermate controls. $\boldsymbol{H}$, Determination of mRNA expression levels for Pdgfrb in the brain pericyte TR-PCT1 cells transfected with Bmal1 siRNA (siControl, $n=5$; siBmal1, $n=3$ ). ${ }^{* *} p<0.01$ compared with cells transfected with siControl.

transporters expressed in the brain endothelium under physiological or pathological conditions (Zloković et al., 1987, 1990). In addition, several BBB peptide transport mechanisms exist, including receptor-mediated, adsorptive-mediated, carrier-mediated, and nonspecific passive diffusion (Zloković, 1995). Clinical studies have also reported BBB dysfunction and brain inflammation in patients with psychiatric disorders (Shalev et al., 2009; Najjar et al., 2013). The previous report by Musiek et al. (2013) showed that Bmall ${ }_{\text {nestin }}^{-1-}$ mice exhibited several neuronal deficits, such as axonal terminal degeneration, disrupted resting-state functional connectivity, and widespread astrocyte activation. Our current findings support the hypothesis that decreased expression of the circadian clock component induces psychiatric or neurodegenerative disease by decreasing BBB integrity. Although many studies have identified the functional importance of clock genes in the brain, we are the first to directly demonstrate the involvement of the circadian clock component in $\mathrm{BBB}$ integrity.

(Figure legend continued.) Nestin-GFP ${ }^{+}$cells in a confocal image from the immunohistochemical analysis presented in $\boldsymbol{D}(n=3 ; 2-3$ slices per independent mouse). Figure 5-1. Available at 10.1523/JNEUROSCI.3639-16.2017.f5-1. Additional data for Nestin-GFP ${ }^{+}$cells in the brain. $A$, Confocal image of GFP (green) and Hoechst 33342 DNA staining (blue) in the hippocampal dentate gyrus and CA1 and CA3 regions of Nestin-GFP transgenic mice at $8-12$ weeks of age. $B$, Low-magnification images of immunohistochemical staining for CD31, Desmin, CD13, and PDGFR $\beta$ in the cerebral cortex of Nestin-GFP ${ }^{+}$mice. C, Representative confocal laser-scanning orthoimage of z-stacks of CD31, Desmin, and CD13 in the cerebral cortex of Nestin-GFP ${ }^{+}$mice.
Pericytes are embedded within the vascular basement membrane of blood vessels and control BBB permeability and cerebral blood flow (Winkler et al., 2011). Accumulating evidence suggests that pericyte degeneration induces $\mathrm{BBB}$ breakdown and neuronal degeneration following the accumulation of bloodderived neurotoxins (Mann et al., 1985; Zloković et al., 1990; Bell et al., 2010) in complex neurological disorders, such as Alzheimer's disease (Zloković et al., 1985a,b, 1987), amyotrophic lateral sclerosis (Zloković, 1995), and retinopathy related to type 2 diabetes mellitus (Nielsen et al., 1997; Zlokovic and Apuzzo, 1997). Bmal1 $1_{\text {nestin }}^{-1-}$ mice exhibited pericyte dysfunction, BBB hyperpermeability, and marked astrocyte activation. These data strongly indicate that genetic disruption of the circadian clock protein affects BBB homeostasis via pericyte dysfunction in vivo.

Our observation that Bmal1 nestin mice exhibit pericyte dysfunction, BBB hyperpermeability, and astrocyte activation provides a novel mechanism as to how circadian clock component Bmal1 regulates pericyte function. PDGF-BB is secreted from endothelial cells and binds to the PDGFR $\beta$ on pericytes, which is essential for the recruitment, proliferation, migration, and attachment of pericytes (Winkler et al., 2011). Studies in mouse models with partially disrupted PDGF-BB/PDGFR $\beta$ signaling showed an age-dependent BBB breakdown (Armulik et al., 2010; Daneman et al., 2010). Our experiments in Nestin-GFP ${ }^{+}$Bmal1 $1^{-1-}$ mice demonstrated that the deletion of Bmall does not affect the number of Nestin-GFP ${ }^{+}$pericytes but rather changes the properties of pre-existing Nestin-GFP ${ }^{+}$pericytes (i.e., decreased PDGFR $\beta$ expression). In addition, silencing experiments illustrated that 
Bmall regulates $P d g f r b$ transcription. Although further experiment should be performed to reveal the mechanisms by which clock genes regulate PDGFR $\beta$ expression; therefore, the disruption of the positive loop of the circadian clock may decrease PDGFR $\beta$ expression, leading to pericyte dysfunction and reduced BBB integrity.

In conclusion, the circadian clock component Bmall regulates BBB homeostasis via regulation of pericyte function. Our findings contribute to an improved understanding of the functions of the non-SCN clock system in a variety of physiological and pathological processes involving BBB hyperpermeability. Thus, Bmall may represent a novel target for the discovery and development of therapies for many neurodegenerative and/or psychiatric disorders related to abnormal BBB integrity.

\section{References}

Adornato B, Lampert P (1971) Status spongiosus of nervous tissue. Electron microscopic studies. Acta Neuropathol 19:271-289. CrossRef Medline

Alliot F, Rutin J, Leenen PJ, Pessac B (1999) Pericytes and periendothelial cells of brain parenchyma vessels co-express aminopeptidase N, aminopeptidase A, and nestin. J Neurosci Res 58:367-378. CrossRef Medline

Armulik A, Genové G, Mäe M, Nisancioglu MH, Wallgard E, Niaudet C, He L, Norlin J, Lindblom P, Strittmatter K, Johansson BR, Betsholtz C (2010) Pericytes regulate the blood-brain barrier. Nature 468:557-561. CrossRef Medline

Asashima T, Iizasa H, Terasaki T, Hosoya K, Tetsuka K, Ueda M, Obinata M, Nakashima E (2002) Newly developed rat brain pericyte cell line, TRPCT1, responds to transforming growth factor-betal and beta-glycerophosphate. Eur J Cell Biol 81:145-152. CrossRef Medline

Bell RD, Winkler EA, Sagare AP, Singh I, LaRue B, Deane R, Zlokovic BV (2010) Pericytes control key neurovascular functions and neuronal phenotype in the adult brain and during brain aging. Neuron 68:409-427. CrossRef Medline

Brett FM, Mizisin AP, Powell HC, Campbell IL (1995) Evolution of neuropathologic abnormalities associated with blood-brain barrier breakdown in transgenic mice expressing interleukin-6 in astrocytes. J Neuropathol Exp Neurol 54:766-775. CrossRef Medline

Daneman R, Zhou L, Kebede AA, Barres BA (2010) Pericytes are required for blood-brain barrier integrity during embryogenesis. Nature 468:562566. CrossRef Medline

Dore-Duffy P, Katychev A, Wang X, Van Buren E (2006) CNS microvascular pericytes exhibit multipotential stem cell activity. J Cereb Blood Flow Metab 26:613-624. CrossRef Medline

Gekakis N, Staknis D, Nguyen HB, Davis FC, Wilsbacher LD, King DP, Takahashi JS, Weitz CJ (1998) Role of the CLOCK protein in the mammalian circadian mechanism. Science 280:1564-1569. CrossRef Medline

Griffin EA Jr, Staknis D, Weitz CJ (1999) Light-independent role of CRY1 and CRY2 in the mammalian circadian clock. Science 286:768-771. CrossRef Medline

Kondratova AA, Kondratov RV (2012) The circadian clock and pathology of the ageing brain. Nat Rev Neurosci 13:325-335. CrossRef Medline

Kume K, Zylka MJ, Sriram S, Shearman LP, Weaver DR, Jin X, Maywood ES, Hastings MH, Reppert SM (1999) mCRY1 and mCRY2 are essential components of the negative limb of the circadian clock feedback loop. Cell 98:193-205. CrossRef Medline

Lendahl U, Zimmerman LB, McKay RD (1990) CNS stem cells express a new class of intermediate filament protein. Cell 60:585-595. CrossRef Medline

Mann GE, Zlokovic BV, Yudilevich DL (1985) Evidence for a lactate transport system in the sarcolemmal membrane of the perfused rabbit heart: kinetics of unidirectional influx, carrier specificity and effects of glucagon. Biochim Biophys Acta 819:241-248. CrossRef Medline

Mignone JL, Kukekov V, Chiang AS, Steindler D, Enikolopov G (2004) Neural stem and progenitor cells in nestin-GFP transgenic mice. J Comp Neurol 469:311-324. CrossRef Medline

Mühlbauer E, Wolgast S, Finckh U, Peschke D, Peschke E (2004) Indication of circadian oscillations in the rat pancreas. FEBS Lett 564:91-96. CrossRef Medline
Musiek ES, Lim MM, Yang G, Bauer AQ, Qi L, Lee Y, Roh JH, Ortiz-Gonzalez X, Dearborn JT, Culver JP, Herzog ED, Hogenesch JB, Wozniak DF, Dikranian K, Giasson BI, Weaver DR, Holtzman DM, Fitzgerald GA (2013) Circadian clock proteins regulate neuronal redox homeostasis and neurodegeneration. J Clin Invest 123:5389-5400. CrossRef Medline

Najjar S, Pearlman DM, Devinsky O, Najjar A, Zagzag D (2013) Neurovascular unit dysfunction with blood-brain barrier hyperpermeability contributes to major depressive disorder: a review of clinical and experimental evidence. J Neuroinflammation 10:142. CrossRef Medline

Nielsen S, Nagelhus EA, Amiry-Moghaddam M, Bourque C, Agre P, Ottersen OP (1997) Specialized membrane domains for water transport in glial cells: high-resolution immunogold cytochemistry of aquaporin-4 in rat brain. J Neurosci 17:171-180. Medline

Ono N, Ono W, Mizoguchi T, Nagasawa T, Frenette PS, Kronenberg HM (2014) Vasculature-associated cells expressing nestin in developing bones encompass early cells in the osteoblast and endothelial lineage. Dev Cell 29:330-339. CrossRef Medline

Schachtrup C, Ryu JK, Helmrick MJ, Vagena E, Galanakis DK, Degen JL, Margolis RU, Akassoglou K (2010) Fibrinogen triggers astrocyte scar formation by promoting the availability of active TGF- $\beta$ after vascular damage. J Neurosci 30:5843-5854. CrossRef Medline

Schibler U (2007) The daily timing of gene expression and physiology in mammals. Dialogues Clin Neurosci 9:257-272. Medline

Segura I, De Smet F, Hohensinner PJ, Ruiz de Almodovar C, Carmeliet P (2009) The neurovascular link in health and disease: an update. Trends Mol Med 15:439-451. CrossRef Medline

Shalev H, Serlin Y, Friedman A (2009) Breaching the blood-brain barrier as a gate to psychiatric disorder. Cardiovasc Psychiatry Neurol 2009:278531. CrossRef Medline

Shimba S, Ishii N, Ohta Y, Ohno T, Watabe Y, Hayashi M, Wada T, Aoyagi T, Tezuka M (2005) Brain and muscle Arnt-like protein-1 (BMAL1), a component of the molecular clock, regulates adipogenesis. Proc Natl Acad Sci U S A 102:12071-12076. CrossRef Medline

Shimba S, Ogawa T, Hitosugi S, Ichihashi Y, Nakadaira Y, Kobayashi M, Tezuka M, Kosuge Y, Ishige K, Ito Y, Komiyama K, Okamatsu-Ogura Y, Kimura K, Saito M (2011) Deficient of a clock gene, brain and muscle Arnt-like protein-1 (BMAL1), induces dyslipidemia and ectopic fat formation. PLoS One 6:e25231. CrossRef Medline

Storch KF, Lipan O, Leykin I, Viswanathan N, Davis FC, Wong WH, Weitz CJ (2002) Extensive and divergent circadian gene expression in liver and heart. Nature 417:78-83. CrossRef Medline

Storch KF, Paz C, Signorovitch J, Raviola E, Pawlyk B, Li T, Weitz CJ (2007) Intrinsic circadian clock of the mammalian retina: importance for retinal processing of visual information. Cell 130:730-741. CrossRef Medline

Takarada T, Kodama A, Hotta S, Mieda M, Shimba S, Hinoi E, Yoneda Y (2012a) Clock genes influence gene expression in growth plate and endochondral ossification in mice. J Biol Chem 287:36081-36095. CrossRef Medline

Tanaka M, Yamaguchi K, Tatsukawa T, Nishioka C, Nishiyama H, Theis M, Willecke K, Itohara S (2008) Lack of Connexin43-mediated bergmann glial gap junctional coupling does not affect cerebellar long-term depression, motor coordination, or eyeblink conditioning. Front Behav Neurosci 2:1. CrossRef Medline

Tronche F, Kellendonk C, Kretz O, Gass P, Anlag K, Orban PC, Bock R, Klein R, Schütz G (1999) Disruption of the glucocorticoid receptor gene in the nervous system results in reduced anxiety. Nat Genet 23:99-103. CrossRef Medline

Winkler EA, Bell RD, Zlokovic BV (2011) Central nervous system pericytes in health and disease. Nat Neurosci 14:1398-1405. CrossRef Medline

Wulff K, Gatti S, Wettstein JG, Foster RG (2010) Sleep and circadian rhythm disruption in psychiatric and neurodegenerative disease. Nat Rev Neurosci 11:589-599. CrossRef Medline

Yamaguchi S, Mitsui S, Miyake S, Yan L, Onishi H, Yagita K, Suzuki M, Shibata S, Kobayashi M, Okamura H (2000) The 5' upstream region of $\mathrm{mPer} 1$ gene contains two promoters and is responsible for circadian oscillation. Curr Biol 10:873-876. CrossRef Medline

Young ME, Razeghi P, Cedars AM, Guthrie PH, Taegtmeyer H (2001) Intrinsic diurnal variations in cardiac metabolism and contractile function. Circ Res 89:1199-1208. CrossRef Medline

Zhu Y, Romero MI, Ghosh P, Ye Z, Charnay P, Rushing EJ, Marth JD, Parada LF (2001) Ablation of NF1 function in neurons induces abnormal 
development of cerebral cortex and reactive gliosis in the brain. Genes Dev 15:859-876. CrossRef Medline

Zlokovic BV (1995) Cerebrovascular permeability to peptides: manipulations of transport systems at the blood-brain barrier. Pharm Res 12:13951406. CrossRef Medline

Zlokovic BV (2008) The blood-brain barrier in health and chronic neurodegenerative disorders. Neuron 57:178-201. CrossRef Medline

Zlokovic BV, Apuzzo ML (1997) Cellular and molecular neurosurgery: pathways from concept to reality-part I: target disorders and concept approaches to gene therapy of the central nervous system. Neurosurgery 40:789-803. CrossRef Medline

Zlokovic BV, Begley DJ, Chain-Eliash DG (1985a) Blood-brain barrier per- meability to leucine-enkephalin, D-alanine2-D-leucine5-enkephalin and their N-terminal amino acid (tyrosine). Brain Res 336:125-132. CrossRef Medline

Zloković BV, Segal MB, Begley DJ, Davson H, Rakić L (1985b) Permeability of the blood-cerebrospinal fluid and blood-brain barriers to thyrotropinreleasing hormone. Brain Res 358:191-199. CrossRef Medline

Zloković BV, Lipovac MN, Begley DJ, Davson H, Rakić L (1987) Transport of leucine-enkephalin across the blood-brain barrier in the perfused guinea pig brain. J Neurochem 49:310-315. CrossRef Medline

Zlokovic BV, Hyman S, McComb JG, Lipovac MN, Tang G, Davson H (1990) Kinetics of arginine-vasopressin uptake at the blood-brain barrier. Biochim Biophys Acta 1025:191-198. CrossRef Medline 